\title{
Production and use of educational technologies in nursing post-graduation
}

\author{
Produção e uso de tecnologias educacionais na pós-graduação em Enfermagem \\ Producción y uso de tecnologías educativas en el posgrado en enfermeira
}

\section{Priscila de Oliveira Cabral Melo' ORCID: 0000-0002-6105-2248}

Ryanne Carolynne Marques Gomes Mendes' ORCID: 0000-0001-7554-2662

Francisca Márcia Pereira Linhares ORCID: 0000-0001-9778-5024

Tatiane Gomes Guedes ORCID: 0000-0001-7149-2290

'Universidade Federal de Pernambuco. Recife, Pernambuco,

Brazil.

How to cite this article: Melo POC, Mendes RCMG, Linhares FMP, Guedes TG. Production and use of educational technologies in nursing post-graduation. Rev Bras Enferm. 2022;75(5):e20210510. https://doi.org/10.1590/0034-7167-2021-0510

\section{Corresponding author:} Priscila de Oliveira Cabral Melo E-mail: priscila.cabral@live.com

EDITOR IN CHIEF: Antonio José de Almeida Filho ASSOCIATE EDITOR: Maria Itayra Padilha

Submission: 08-04-2021

Approval: 10-03-2021

\begin{abstract}
Objective: To report, under the light of Gardner's Theory of Multiple Intelligences, the experience of students with advanced educational practices, involving the production and use of technologies in the postgraduation nursing course of the Universidade Federal de Pernambuco. Methods: Experience report of students from the post-graduation nursing program from the Universidade Federal de Pernambuco, about the production of knowledge using educational technology and the application of active methodologies in the teachinglearning process for face-to-face and distance teaching. Results: The post-graduate students participated in the educational process in a creative way, both during in-person and distance teaching. They created: domino games, educational videos, parodies, conceptual maps, virtual role-playing, an interactive quiz, among others. Final considerations: The experience of the students with the advanced educational practices, including the production and use of technologies in nursing post-graduation showed that the teaching-learning process can be innovative and planned to go beyond traditional methods.
\end{abstract}

Descriptors: Education, Graduate; Nursing; Teaching Materials; Educational Technology; Education.

\section{RESUMO}

Objetivo: Relatar, à luz da Teoria das Inteligências Múltiplas de Gardner, a experiência de discentes sobre as práticas educacionais avançadas com a produção e uso de tecnologias no curso de pósgraduação em Enfermagem da Universidade Federal de Pernambuco. Métodos: Relato de experiência de discentes do Programa de Pós-graduação em Enfermagem da Universidade Federal de Pernambuco sobre a produção do conhecimento mediante o uso de tecnologias educacionais e acerca da aplicabilidade de metodologias ativas no processo de ensino-aprendizagem no ensino presencial e remoto. Resultados: Os pós-graduandos participaram do processo educacional de forma criativa, tanto no contexto presencial quanto remoto. Construíram: jogo de dominó, vídeos educativos, paródias, mapas conceituais, encenações virtuais, quiz interativo, entre outros. Considerações finais: A experiência dos discentes sobre as práticas educacionais avançadas com a produção e uso de tecnologias na pós-graduação em Enfermagem mostrou que o processo de ensino-aprendizagem pode ser inovador e pensado para além do tradicionalismo.

Descritores: Educação de Pós-Graduação; Enfermagem; Materiais de Ensino; Tecnologia Educacional; Educação.

\section{RESUMEN}

Objetivo: Relatar, basada en la Teoría de las Inteligencias Múltiples de Gardner, experiencia de discentes sobre las prácticas educativas avanzadas con la producción y uso de tecnologías en el posgrado en Enfermería de la Universidad Federal de Pernambuco. Métodos: Relato de experiencia de discentes del Posgrado en Enfermería de la Universidad Federal de Pernambuco sobre la producción del conocimiento mediante el uso de tecnologías educativas y aplicabilidad de metodologías activas en el proceso de enseñanza-aprendizaje en la enseñanza presencial y remota. Resultados: Los pos graduandos participaron del proceso educativo de manera creativa, tanto en el contexto presencial cuanto remoto. Construyeron: dominó, vídeos educativos, parodias, mapas conceptuales, escenificaciones virtuales, concurso interactivo, entre otros. Consideraciones finales: La experiencia de los discentes sobre las prácticas educativas avanzadas con la producción y uso de tecnologías en el posgrado en Enfermería mostró que el proceso de enseñanza-aprendizaje puede ser innovador y pensado además del tradicionalismo.

Descriptores: Educación de Postgrado; Enfermería; Materiales de Enseñanza; Tecnología Educacional; Educación. 


\section{INTRODUCTION}

Technologies have changed paradigms, increasing the speed in which information is transferred, aiding in the development of daily activities, and contributing greatly for the teaching-learning process. In the field of nursing, technologies stand out both for educational and nursing assistance purposes ${ }^{(1)}$.

In regard to education, technologies have occupied a central role in the 21 st century and are increasingly used in teaching, be it in graduation or post-graduation nursing courses, to encourage and innovate education. Not only they facilitate more dynamic classes, but they also encourage the student to be a co-participant of their teaching-learning process. From this perspective, educational technologies promote a more active, dynamic, and instigating technology ${ }^{(1)}$.

The production of educational technology, with the use of active methodologies, has been encouraged during the teaching-learning process during post-graduation. These technologies, associated with a participative pedagogical process, have strengthened learning, making it innovative and up-to-date ${ }^{(3-4)}$. It also allows for the acquisition of knowledge and abilities, which leads to a positive impact on the formation of the masters and/or doctors of the future ${ }^{(2)}$.

Their formation must be based on strategies that respond to the several demands of the students, as well as to their many ways of learning and of putting the content they learned into practice in an active methodology, which allows the student to take the main role in the teaching-learning process(2).

Gardner's Theory of Multiple Intelligences (TMI) is a theoretical framework to give a base to this project and subsidize these needs. TMI is a new way to think and teach, mediated by the idea that all human beings have the competences, abilities, and multiple intelligences: linguistic, logical-mathematical, musical, spatial, bodily-kinesthetic, interpersonal, intrapersonal, and existentialist ${ }^{(5)}$.

In the last decades, due to the fast changes in the educational context, the teaching learning process in post-graduation has been changing: as an example, teaching practices have been going through changes in regard to the production and use of educational technology ${ }^{(2)}$. One of the significant causes for these changes is related to the COVID-19 pandemic. In the context of the pandemic, changes have been made in the dynamics of education, and distance teaching has become the main modality of teaching.

Active methodologies, in turn, started to be more frequently used, to make the teachinglearning process and the interactions between professors and students in a virtual environment more dynamic ${ }^{(5)}$.

To encourage a more participative, autonomous, and engaging teaching, as well as to minimize the impact of social distancing on the process of teaching-learning of students, many technological resources have been used in the educational setting. The use of active methodologies on a virtual environment started to be required more, to promote dialogue and encourage the student to assume the main role, in addition to instigating problematization, the production of plural knowledge, and to fomenting reflective criticism about the content discussed ${ }^{(6)}$.

Based on the perspective according to which concepts or subjects must be taught in many different ways to activate different intelligences or their combination ${ }^{(5,7)}$, disciplines from the nursing post-graduation course from the Universidade Federal de Pernambuco (Nursing PGP - UFPE) have provided professors with the experience, production, use, and application of the new educational technologies through active methodologies.

The activities based on TMI encourage customized, creative, and motivating teaching ${ }^{(7)}$. Furthermore, they consider the differences between individuals and the organization of the teachinglearning process, integrating the participants in the confrontation of challenges and on the discovery of the potential of each of them.

Therefore, we felt the need to disseminate and give visibility to the successful experiences involving practical situations and technological innovation in teaching. As a result, this article aimed to produce experience reports that can be applied to the different educational contexts, since publishing these actions could have an impact towards the implementation of more innovative and engaging teaching.

\section{OBJECTIVE}

To report, under the light of Gardner's Theory of Multiple Intelligences, the experience of students involving advanced educational practices that involve the production and use of technologies in the post-graduation nursing course of the Universidade Federal de Pernambuco.

\section{METHODS}

\section{Ethical aspects}

This study is an experience report, and, as a result, the appreciation of the Research Ethics Committee (CEP) was not required.

\section{Type of study}

This is a report of the experience of students about the production and use of educational technologies and the applicability of active methodologies in the teaching-learning process of both inperson and distance teaching subjects, under the light of Gardner's Theory of Multiple Intelligences. The experience took place from March 2019 to December 2020. During 2020, the activities were in-person, but starting in June 2020, they took place remotely.

This report discusses the advanced educational practices applied to the pedagogical dynamics used by the UFPEss PhD course. The study seeks to highlight and describe practical situations in which different types of educational technologies, that were produced and used during the disciplines, were used.

\section{Study setting}

The setting was formed by the in-person and distance classes of the PhD course that took place in the nursing PGP at UFPE, in the city of Recife, in the state of Pernambuco, Brazil.

\section{Methodological procedures}

Elaborating the methodological itinerary of this report started with the issue that involves the pedagogical approach to the 
content taught in post-graduation and the encouragement to the elaboration and use of technological resources in this setting. The description of the experience is based on the TMI and on the understanding that each individual develops specific types of intelligence.

The students were divided in groups from four to six people. Each group was tasked with topics for the in-person disciplines: Technologies in health education and basic education; Theoreticalmethodological concepts and the practice of higher education; Education in health and nursing; and Historical, social, and anthropological bases of family health. Subjects for distance classes were also were developed: Epistemological concepts of being and doing in health-nursing sciences and education; Social epidemiology; and the Ethics and bioethics of being, knowing, and doing.

The groups were free to develop the content and to use creative and participative teaching methodologies according to the time of exposure that was previously determined by the professors. It should be mentioned that the topics were broad and divided in sub-topics. During the planning and creation of the presentations, the involvement and the interest of the students in searching for innovative methodologies to present the content were noticeable.

\section{Data collection and organization}

The descriptive structure of this report was based on TMI implications for academic formation. To report the information in a robust way, students, syllabuses, and written and photographic records of the classes were consulted.

\section{RESULTS}

The experiences reported were in the context of in-person (in 2019) and distance (in 2020) pedagogical practices. The priority of the program, in addition to teaching theoretical content, was to instigate the students to stimulate as much of their abilities types of intelligence - as possible, by cultivating creativity and dynamics, planning, and elaborating educational technologies that could be used to conduct the discussion of the topics. The objective was to address philosophical, political, technical, or pedagogical topics in a dynamic and more playful way.

In all subjects, creative participation was motivated, with the application of active methodologies in the educational process. These have guided the planning, the research of content, and the construction of presentations about previously determined topics. At first, the students were separated in groups of up to six members. Then, they received guidance about the objective of each activity, the time each presentation should last, and how they would be evaluated. The presentations were evaluated by both professors and students.

In the discipline Technologies in health education and basic education, the students received an evaluation form with specific items to evaluate the presentation of each person. The evaluations were quantitative and qualitative, addressing the resources used for the presentation, the posture, the tone of voice, the group's respect to the time limit, the knowledge about the content, among other elements.
For the development of each activity, the groups of students carried out meetings, researches, interviews, and consulted experts on the subject, aiming to create educational technologies. An evidence of this were the different educational technologies produced and used during the classes, such as: dominoes and educational videos about nursing theory; simulation of talk shows and variety shows to discuss themes related to the most vulnerable population; cordel, a type of regional Brazilian poetry, to address health education and the particularities experienced by different Brazilian regions; conceptual maps to discuss about the great education theoreticians and the applicability of their main theories.

There were also parodies to address Paulo Freire's pedagogical concepts; role-playing to explain how nursing care worked in different periods of history; a physical thread going through the class with questions and answers hanging from it about pedagogical models; the production of an electronic album divided in sections about educational technologies; a series of competitions to discuss themes related to health education; among other activities that enriched the educational process and increased the valorization of human capacities, through the recruiting of different types of intelligence.

On the other hand, in the distance classes that took place during the COVID-19 pandemic, the students had the challenge of giving a new meaning to the educational process, by creating pedagogical resources that could make the content more interactive and capable of encouraging the different human intelligences. Google Classroom, Google Meet, and other sites and applications were used. In this setting, the abilities were developed through an on-line pedagogical process based on TMI.

In addition to the active methodologies, the students also explored the digital environment, with the production of educational technologies, such as games of questions and answers in the form of an interactive quiz about the epidemiology of arterial hypertension, the creation of a word cloud about the Environmental Theory by Florence Nightingale; explanatory videos about ethics on the context of telehealth and the simulation of variety shows about the theories of social epidemiology; cordel to address health education practices; and virtual role playing to address topics related to ethics and bioethics.

Other resources produced and used included mental maps and infographics, about concepts such as ethics, morals, bioethics, maleficence, and non-maleficence, from the etymology of the words to the applicability of the concepts on the practical context of nursing.

All these educational technologies that were constructed and used allowed students to be co-participants in the teaching-learning process, stimulating their creativity, problem-solving capabilities, and the application of the active methodologies. This made it possible to enhance the formation of these masters and doctors, in addition to encourage the other participants in the disciplines to develop a critical and reflective thought about the topics discussed.

\section{DISCUSSION}

This study innovates as it reports, under the light of Gardner's Theory of Multiple Intelligences, the experience of students from the nursing PGP-UFPE with the elaboration and use of educational 
technologies in the pedagogical process, considering a parallel established between the reality of education before and after the context of the COVID-19 pandemic.

Based on the understanding that each human being has multiple intelligences, and that working with them is essential in the educational context, educational technologies were constructed and used to activate these intelligences, aiming to value the culture, symbolic systems, language, music, body movement, among other fields ${ }^{(5)}$.

The use of active methodologies during the classes of the nursing PGP - UFPE showed itself to be a strong pedagogical strategy that should be used in the teaching-learning process of the nursing postgraduation student, before, during, and after the context of the pandemic. Furthermore, it showed the importance of an easy-going, dialogical, and inclusive approach to pedagogical actions.

Approaching teaching in an inclusive way can unveil personal strengths, abilities, and characteristics, in addition to fomenting the development of different human intelligences that can be explored and valued as aspects specific to the integral development of each individual ${ }^{(5)}$.

The different activities developed using the educational technologies broke paradigms in regard to the image of postgraduation, which is usually seen as formal, with strict disciplines based on academic rigor.

The use and production of new educational technologies and the application of active methodologies were found to be essential for the critical formulation of the post-graduation students, since they make professor-student and/or student-professor learning more autonomous, reflective, and transversal ${ }^{(2-6)}$.

Experiences such as the ones reported in this study encourage the reflection about a facet of the postgraduation that too often goes unseen: a collaborative, humane, innovative facet, where the student, while being cognitively encouraged, is horizontally connected with the professor, and, as such, becomes a participant of their own learning.

Some post-graduation courses have worked towards that end in order to encourage the use and production of educational technologies, enhance different cognitive functions, improve the teaching-learning process, and, therefore, contribute with the formation of future professors. Among the technologies explored, the educational videos, which have been frequently used during classes, stand out, since they enhance learning by explaining theoretical concepts and using images that stimulate the imagination ${ }^{(7)}$.

In the nursing PGP - UFPE, due to how much it facilitates to handle and maintain the attention of the student as the content is addressed ${ }^{(7)}$, the use and production of videos have been expressive, both for in-person and distance classes. The use of this technology is in accordance with the TMI, since it unites language, auditory, and visual aspects, and other elements, that significantly favor linguistic intelligence ${ }^{(5)}$.

Furthermore, to promote virtual interaction and contribute for the teachinglearning process, especially considering that the dialogue and the problematization of the content are encouraged, the students were motivated to construct and use interactive games and simulations as didactic tools to enable the development of autonomy and logical reasoning ${ }^{(4)}$.
Educational games are potential resources to complement the teaching-learning process, since they help apprehending the content and promote more engagement, thus stimulating the learning process. From a pedagogical standpoint, the elaboration and use of educational games should associate the competences that are intrinsic to the subject and the intellectual competences, to favor cognition ${ }^{(8)}$.

Simulation and dramatization are teaching-learning tools that are widely used during the academic formation in the scope of health. Therefore, they present benefits as they encourage bodily-kinesthetic, linguistic, interpersonal, intrapersonal, and existential intelligences ${ }^{(5)}$, promoting self-confidence, better communication, stimulating critical and reflective thought, motivating, among other benefits ${ }^{(9)}$.

In this regard, the application of the pedagogical resources for methodological goals in postgraduation strengthens and triggers learning, while making the educational process more fluid and stimulating. Constructing and using educational technologies showed the importance of making the educational process more playful and participative.

In these experiences, in addition to the teaching of the content, the students could study about a new pedagogical culture of learning, focused on TMI. As a result, they developed and perfected abilities and competences, such as group communication, planning, time management, scientifically-based creation of educational technologies, leadership, the ability to criticize, in addition to a more playful, dynamic, and dialogic pedagogical practice. As a result, they could stimulate their musical, linguistic, interpersonal, intrapersonal, and body-kinesthetic intelligences.

The studies used as a framework for the construction and use of the educational technologies made the students aware of an element that is essential when one discusses educational technologies: the validation of content and appearance, to verify how adequate a technology is to the objective towards which it was developed ${ }^{(10)}$. Validating an educational technology allows for it to be disseminated and used in other realities, guaranteeing that it is adequate and that, later, it can be applied to reach the objective it was planned for.

The application of the active methodologies on the educational process encouraged autonomy and motivated the students to take a prominent role in the teaching-learning process, bringing pedagogical advantages during the entire educational process ${ }^{(2)}$.

Post-graduation must give the student a fertile ground for their formation to go beyond a content-focused logic, through the development and improvement of cognitive functions and of critical awareness. The students should be, at all times, encouraged to be proactive and to carry out transformative action. They should be critical, reflective, and creative individuals, so they can be formed as professors that are active and raise questions about relevant issues ${ }^{(2,6)}$. To that end, an education based on theoretical references and based on the integration of media, to add value to the educational process, must be given more and more support.

\section{Study limitations}

The limitations the study include the fact that the disciplines analyzed had only one group of students; no evaluation instrument was used to evaluate the perception of the professors; and 
the educational technologies produced and applied are still to be evaluated and registered by the post-graduation students on the eduCapes platform.

\section{Contributions to the field}

This study contributes to encourage the production of new reports, on a national and international level, about the successful pedagogical practices that use active methodologies, including the use/production of educational technologies in post-graduation classes. Furthermore, it collaborates as part of a body of evidences related to educational practices that involve technological innovation in a context of educational interventions in the formation of masters and doctors.

\section{FINAL CONSIDERATIONS}

The experiences of producing and using the educational technologies as pedagogical resources to develop in-person or distance postgraduation activities incited, in the post-graduation students, a new perception about the pedagogical practice in the post-graduation, showing the importance to stimulate different intelligences.

Pedagogical activities implemented in the nursing PGP - UFPE disciplines were innovative, instigating, and showed a teaching-learning process that goes beyond traditional content-focused ones. Considering how broadly these resources can be used and applied on the actions of the nurse, they can also be applied outside of the academic context, as in the assistance to the team (permanent education) and on the practice of assistance with users (education in health).

Reporting the experience as post-graduation students and future professors, having the TMI as a theoretical framework, allowed for reflections and motivated the dissemination of this constructivist and innovative pedagogical practice in other in-person or remote realities. Therefore, we suggest that the students and professors from other institutions should publish their experiences related to the production and use of education technologies, and on the applicability of active methodologies to advance knowledge. It is important, therefore, to give visibility to the use of these educational resources in the practice of future masters and doctors, instigating the production of new studies that use these technologies when they are applied in other contexts.

\section{FUNDING}

To the Coordination for the Improvement of Higher Education Personnel for the scholarship offered to the first and second authors.

\section{REFERENCES}

1. Fernandes MNDF, Esteves RB, Teixeira CAB, Gherardi-Donato ECDS. The present and the future of Nursing in the Brave New Worl. Rev EsC Enferm USP. 2018;52:e03356. doi: http://dx.doi.org/10.1590/s1980-220x2017031603356.

2. Sobral JPCP, Viana MER, Lívio TA, Santos AG, Costa BGDS, Rozendo CA. Active Methodologies in the Critical Education of. Master's Students in Nursing. Rev Cuid. 2020;11(1):e822. doi: https://doi.org/10.15649/cuidarte.822.

3. Camacho ACLF, Souza VMF. Tecnologias Educacionais no ensino híbrido de Enfermagem. Res Soc Dev. 2021;10(9):e40210918192. doi: https://doi.org/10.33448/rsd-v10i9.18192

4. Martins FDP, Leal LP, Linhares FMP, Santos AHDS, Leite GDO, Pontes CM. Effect of the board game as educational technology on schoolchildren's knowledge on breastfeeding. Rev Latino-Am Enfermagem. 2018;26:e3049. doi: http://dx.doi. org/10.1590/1518-8345.2316.3049.

5. Gardner H. Frames of mind: the theory of multiple intelligences. New York: Basic Books; 2011. 467p.

6. Rad FA, Otaki F, Baqain Z, Zary N, Al-Halabi M. Rapid transition to distance learning due to COVID-19: Perceptions of postgraduate dental learners and instructors. Plos one. 2021;16(2):e0246584. doi: https://doi.org/10.1371/journal.pone.0246584.

7. Iskru VV, Schulz J. How Postgraduate Students Use Video to Help Them Learn. Contemp Educ Technol. 2020;12(2):e0253683. doi: https://doi. org/10.1371/journal.pone.0246584.

8. Girão ALA, Sampaio RL, Aires SF, Oliveira ICL, Oliveira SKP, Carvalho REFL. Medsafe: prototype of a virtual game on the preparation and administration of medications. Rev Min Enferm. 2019;23:e-1239. doi: https://doi.org/10.5935/1415-2762.20190087.

9. Negri EC, Mazzo A, Martins JCA, Pereira Junior GA, Almeida RGS, Pedersoli CE. Clinical simulation with dramatization: gains perceived by students and health professionals. Rev Latino-Am Enfermagem. 2017;25:e2916. doi: http://dx.doi.org/10.1590/1518-8345.1807.2916.

10. Teixeira E. Desenvolvimento de Tecnologias Cuidativo-Educacionais. Porto Alegre: Moriá; 2020. 262p. 